\title{
MENELUSURI JEJAK DAN KIPRAH KIAI KHOLIL AL-BANGKALANI
}

\author{
Aah Syafaah \\ IAIN Syekh Nurjati Cirebon (aah.syafaah2002@gmail.com)
}

\begin{abstract}
Kiai Kholil is a scholar of international scale and a pivot of power for the synergy of the scholars network of santri. Specifically, in the land of Madura and Tapal Kuda ranging from Situbondo, Banyuwangi, Probolinggo and Bondowoso with the network of Pesantren Sidogiri Pasuruan and Talangsari Jember. By this coordination he succeeded to gather those social groups through the Sabilillah-Hizbullah laskar which also connected the kinship line of his predecessors. He was able to capture the hidden potentials behind the land and Madurese community, as Snouck Hurgronje had assessed as central to the network of scholars of santri in Java. This paper intends to trace the life of Kiai Kholil Al-Bangkalani as one of the influential clerics of his time. The influence was built not only by the kinship line it possesses, but also pioneered with great soul and expertise in various sciences and studies of social religious fields of society. His thoughts were contained in a number of works that continue to adorn the treasury of science from the past until today.
\end{abstract}

Keywords: Thought, Madurese, Ulama, Kiai Kholil

\begin{abstract}
Abstrak
Kiai Kholil merupakan seorang ulama yang berskala internasional dan menjadi poros kekuatan bagi sinergisasi jaringan ulama santri secara nasional. Khususnya, di tanah Madura dan Tapal Kuda mulai dari Situbondo, Banyuwangi, Probolinggo dan Bondowoso dengan jaringan Pesantren Sidogiri Pasuruan dan Talangsari Jember. Koordinasi ini berhasil beliau himpun melalui laskar Sabilillah-Hizbullah yang juga menghubungkan garis kekerabatan dari para pendahulunya. Beliau mampu menangkap potensi tersembunyi di balik tanah dan masyarakat Madura, sebagaimana yang telah dinilai oleh Snouck Hurgronje sebagai sentral dari jaringan ulama santri di Jawa. Tulisan ini bermaksud menelusuri jejak kehidupan Kiai Kholil AlBangkalani sebagai salah satu ulama berpengaruh pada masanya. Pengaruh itu dibangun tidak hanya oleh garis kekerabatan yang dimilikinya saja, namun juga dirintis dengan jiwa besar dan kepiawaiannya dalam pelbagai ilmu dan kajian bidang sosial keagamaan masyarakat. Pemikirannya pun tertuang dalam sejumlah karya yang terus menghiasi khazanah keilmuan dari dulu hingga saat ini.
\end{abstract}

Kata-kata Kunci: Pemikiran, Madura, Ulama, Kiai Kholil

\section{A. Pendahuluan}

Masyarakat Madura merupakan salah satu contoh paling nyata untuk menampilkan keragaman dan kemajemukan Nusantara. Hal ini tampak dari bahasa, kebudayaan, kekayaan kuliner dan tradisi yang melekat kuat di tengah masyarakatnya, yang tentu saja berbeda dengan masyarakat Jawa dan juga suku-suku bangsa lainnya di Indonesia.
Khususnya dalam hubungan antara masyarakat dengan Kiai, masyarakat Madura sangat dipengaruhi oleh figuritas seorang Kiai dibandingkan dengan institusi pemerintah atau lainnya. Bahkan hubungan antara Kiai dan masyarakat sudah seperti hubungan antara ayah dan anak. ${ }^{1}$ Maka wajar jika kemudian seorang Kiai akan menempati kelas sosial teratas di tengah masyarakat

\footnotetext{
${ }^{1}$ Lihat Muhammad Kosim, "Kyai dan Blater: Elite Lokal dalam Masyarakat Madura", Karsa XII, (2007: hlm. 162).
} 
Madura. Di mana stratifikasi sosial yang dilihat dari sudut pandang agama hanya ada dua lapisan yaitu santre (santri) dan benni santre (bukan santri).

Lebih jauh, seorang Kiai di sana akan memiliki pengaruh yang beragam mulai dari asal-usul genealogis (keturunan), kedalaman ilmu agama yang dimiliki, kepribadian, kesetiaan menyantuni umat dan faktor pendukung lainnya. $^{2}$

Salah satu ulama besar yang hingga saat ini masih sangat berpengaruh di Madura adalah Kiai Kholil. Meski saat ini beliau sudah meninggal, tetapi kiprah dan perjuangannya masih melekat kuat di tengah-tengah masyarakatnya, hingga membuat masyarakatnya masih sangat menghormati keturunan beliau. Padahal dilihat dari sisi yang lain, karakter asli masyarakat Madura, di mana Kiai Kholil berada dan berhadapan langsung dengan mereka, dikenal memiliki kepribadian teguh, ulet, tegas ketika berbicara dan keras, ${ }^{3}$ bahkan mereka terbiasa melakukan tradisi $\operatorname{carok}^{4}$ untuk menyelesaikan masalah.

${ }^{2}$ Lihat Samsul Ma'arif, "The History of Madura: Sejarah Panjang Madura dari Kerajaan, Kolonialisme sampai kemerdekaan", Yogyakarta: Araska, (2005: hlm. 126).

3 Lihat Syariati Umami, "Sosialisasi Fikih Muhammad Kholil di Bangkalan", skripsi, Jakarta: Universitas Indonesia, (2012: hlm. 56).

${ }^{4}$ Carok adalah kekerasan. Tradisi ini sangat identik di tengah masyarakat Madura. Di mana mereka
Kiai Kholil dikenal sebagai guru yang rendah hati. Bahkan beliau tak segan untuk menuntut ilmu hadits kepada santrinya yaitu Hasyim Asy'ari dengan mendatanginya ke Tebuireng, Jombang. ${ }^{5}$ Jika mendasarkan pada tradisi pesantren, apa yang dilakukan oleh Kiai Kholil ini menjadi hal yang istimewa, bahkan bisa dibilang fenomenal. Meski Kiai Hasyim Asy'ari sendiri sudah memerintahkan kepada muridnya untuk mempersiapkan kamar khusus untuk gurunya tersebut. Tapi Kiai Kholil menolak untuk diperlakukan secara istimewa. Beliau justru ingin menjalani proses pembelajarannya sama seperti santri lainnya.

Dengan begitu, beliau pun tidur seasrama dengan para santri lainnya. Beliau tidak menempati kamar khusus yang sudah disediakan untuknya. Beliau juga mencuci baju sendiri, antri kamar mandi, dan mengambil makanan sendiri. Tapi tetap saja, hal ini menjadi hal yang tidak menyamankan bagi Kiai Hasyim Asy'ari sendiri.

terbiasa menyelesaikan masalah dengan cara ini sebagai bentuk tindakan nyata. Sebabnya bisa beragam seperti untuk menutupi rasa malu karena telah dilecehkan orang lain atau lawan sehingga merasa harga dirinya telah direndahkan, kutipan dari A. Latief Wiyata dalam Syariati Umami, Op Cit.

${ }^{5}$ Lihat Daffy al-Jugjawy, "Ketika Kiai Hasyim dan Kiai Kholil Berebut Menjadi Murid", sumber: www.tirto.id, diakses pada tanggal 12 Juli 2017, pukul 11:51 Wib. 
Sehingga setelah melalui proses pembujukan yang gagal, Kiai Hasyim Asy'ari pun memerintahkan kepada Kiai Kholil untuk mengisi kamar khusus yang sudah disediakan dan menerima setiap layanan yang diberikan untuknya. Karena dengan begitu, Kiai Hasyim Asy'ari bisa memuliakan guru yang pada saat itu menjadi muridnya.

Di sisi lain, masyarakat Madura juga cukup unik jika dilihat dari ikatan kekerabatan dan agama menjadi unsur penting sebagai penanda identitas etnis Madura. Terutama bagi masyarakat Madura, agama Islam adalah bagian yang tidak terpisahkan dari jati dirinya. ${ }^{6}$

\section{B. Profil Kiai Kholil al-Bangkalani}

Nama lengkap beliau adalah Muhammad Kholil bin Abdul Lathif. Tapi nama lengkap dan gelar beliau adalah Kiai al-'Alim al-'Allamah asySyaikh Muhammad Kholil bin Abdul Lathif al-Bangkalani al-Maduri al-Jawi asy-Syafi'i atau lebih dikenal dengan nama Syaikhona Kholil atau Syekh Kholil. Beliau lahir pada hari selasa 11 Jumadil Akhir tahun $1252 \mathrm{H}$ atau tanggal 20 September 1834 M, di Desa Lagundih Kecamatan Ujung Piring, Bangkalan.

\footnotetext{
${ }^{6}$ Kuntowijoyo dalamm Syariati Umami, Ibid.
}

Beliau berasal dari keluarga ulama. Ayahnya bernama K.H. Abdul Lathif yang mempunyai garis keturunan dengan Sunan Gunung Jati. Kakeknya bernama Kiai Hamim, yang merupakan putra dari Kiai Abdul Karim bin Kiai Muharram bin Kiai Asror Karomah bin Kiai Abdullah bin Sayyid Sulaiman. Dengan kata lain, garis yang menghubungkan Kiai Kholil dengan Sunan Gunung Jati adalah melalui Sayyid Sulaiman yang merupakan cucu dari Sunan Gunung Jati dari pihak ibu. ${ }^{7}$

Berikut ini, penulis cantumkan silsilah resmi dari penuturan tidak langsung K.H. R. As'ad Syamsul Arifin, Situbondo, ${ }^{8}$ sebagai berikut: Sunan Gunung Jati- Sayyid Sulaeman Mojoagung (cucu Gunung Jati)- Kiai Abdullah- Kiai Asror Karomah- Kiai Muharrom- Kiai Abdul Karim- Kiai Hamim- Kiai Abdul Lathif- Kiai Muhammad Kholil Bangkalan.

Berdasarkan silsilah tersebut di atas, tingkat interpretasi kesalahan maupun kebenaran masih perlu diteliti lagi karena hal ini berasal dari sejarah lisan dan belum ditemukannya catatan secara utuh. Meskipun demikian, silsilah

\footnotetext{
${ }^{7}$ Lihat Siti Fatimah, 2011, "Peran K.H. Muhammad Kholil dalam Mengembangkan Islam di Bangkalan Madura", skripsi, Jakarta: UIN Syarif Hidayatullah. ${ }^{8}$ Siti Fatimah, "Peran K.H. Muhammad Cholil dalam Mengembangkan Islam di BangkalanMadura”, Skripsi, UIN Jakarta, (2011), Hal. 36.
} 
yang berbeda ditemukan dalam versi K.H. Ali bin Badri Azmatkhan yang menyebutkan bahwa silsilah Kiai Kholil merupakan pertemuan dari beberapa sunan yaitu Sunan Giri, Sunan Ampel, Sunan Kudus, dan Sunan Gunung Jati yang silsilahnya itu dikaitkan dengan marga Azmatkhan. ${ }^{9}$

Masa kecil hingga remajanya, Kiai Kholil memiliki keistimewaan yang bisa dibilang berbeda dengan kebanyakan remaja lainnya. Beliau memiliki minat yang tinggi terhadap ilmu fiqh dan nahwu. Hal ini tercermin dari kemampuannya untuk menghafalkan 1002 bait nadzam Alfiyah Ibnu Malik. Beliau juga telah mampu membaca AlQur'an dengan metode Qira'at Sab'ah.

Sebelum merantau untuk belajar di luar Pulau Madura, Kiai Kholil lebih dulu berguru ke Tuan Guru Dawuh yang lebih dikenal dengan nama Bujuk Dawuh, di Desa Malajeh, Bangkalan. Selain itu, beliau juga belajar kepada Tuan Guru Agung yang dikenal dengan sebutan Bujuk Agung. ${ }^{10}$

Setelah itu, Kiai Kholil mendatangi satu pesantren ke pesantren lainnya untuk belajar ilmu agama. Di antaranya adalah Pesantren Bungah di

${ }^{9}$ Ibid., hlm. 40.

${ }^{10}$ Lihat Saifur Rahman, "Biografi dan Karomah K.H. Mohammad Kholil Bangkalan: Surat kepada Anjing Hitam", Jakarta: Pustaka Ciganjur, (1999: hlm. 80).
Gresik asuhan Kiai Sholeh, Pesantren Langitan Tuban asuhan K.H. Mohammad Noer, Pesantren CangaanBangil asuhan K.H. Asyik, Pesantren Darussalam, Kebon Candi Pasuruan asuhan Kiai Arif, Pesantren SidogiriPasuruan asuhan Kiai Noer Hasan, Pesantren Winongan asuhan Kiai Abu Dzarrin, dan Pesantren Salafiyah Syafi'iyah-Banyuwangi asuhan Kiai Abdul Bashar. Dengan demikian, Kiai Kholil telah memperkuat jaringan keilmuannya dengan beberapa pesantren di Jawa dan Madura sekaligus sebagai seorang santri.

Setelah itu, beliau menikah pada usia 24 tahun dengan Nyai Asyik yang merupakan putri dari Lodra Putih. Hasil dari pernikahan ini, beliau dikaruniai dua orang anak yang kemudian diberi nama Muhammad Imron dan Rohmah. Beliau pun kemudian menikah untuk kedua kalinya dengan Nyai Misi dan dikarunia seorang anak perempuan bernama Asma, yang kelak dinikahkan dengan Kiai Yasin. Beliau pun mendapatkan 11 orang cucu yaitu Malihah, Muhammad Kholil, Muhammad Nasir, Badiyah, Nahilah, Karimah, Nailah, Sayatun, Robi'ah, Hafsah, Qomariyah dan Tajwati. Sedangkan cucu dari Nyai Rohmah ada dua orang yaitu Umar dan Minnah. Selain itu, beliau juga 
mendapatkan tujuh orang cucu dari putranya Muhammad Imron yaitu Romlah, Nadhifah, Amin, Makmun, Nikmah, Urfiah, dan Jamaliyah.

Sementara itu, proses perjalanan pendidikan Kiai Kholil dilanjutkan tak lama setelah beliau menikah. Saat itu, beliau memutuskan untuk belajar ke Mekah. Ongkos perjalanannya, beliau tutupi dari hasil tabungannya selama nyantri di Banyuwangi. Selama proses perjalanan pun, beliau lebih banyak berpuasa untuk mendekatkan dirinya kepada Allah SWT agar diberikan keselamatan sampai tujuan.

Selama di Mekah, beliau juga tak putus semangatnya untuk terus belajar ilmu agama. Saat itu, beliau belajar kepada Syekh Nawawi al-Bantani di Mekah. Berikut ini beberapa nama guru beliau selain yang telah penulis sebutkan di atas, yaitu Syekh Utsman bin Hasan Ad-Dimyathi, Sayyid Ahmad bin Zaini Dahlan di Mekah, Syekh Mustafa bin Muhammad al-Afifi al-Makki di Mekah, Syekh Abdul Hamid bin Mahmud asySyarwani di Mekah, Syaikh Umar Khatib Bima, Syakh Ahmad Khatib Sambas, dan Syaikh Ali Rahbini.

Selain dikenal sebagai seorang pelajar yang tekun. Kiai Cholil juga dikenal sebagai seseorang yang sederhana. Hal ini dibuktikannya dengan cara memakan kulit semangka ketimbang makanan yang biasa dimakan oleh orang pada umumnya. Beliau juga meminum air zam-zam. Kebiasaan makan makanan seperti itu terjadi selama empat tahun dan berhasil mengundang rasa penasaran dari Syaikh Imam Nawawi yang merupakan guru sekaligus sahabatnya. Bukan hanya Imam Nawawi saja yang merasa heran, tapi Syaikh Ahmad Khatib dari Minangkabau, dan Syaikh Ahmad Yasin dari Padang pun merasakan hal yang sama. $^{11}$

Kebiasaan istimewa lainnya dari Syaikh Cholil adalah saat beliau menggunakan bajunya sebagai kertas untuk menulis semua pelajaran yang beliau dapatkan dari guru-gurunya. Maka tak heran jika semua baju yang beliau punya hanya berwarna putih. Saat beliau sudah berhasil menghafalkan semua catatan itu di luar kepala. Maka beliau baru bisa mencuci bajunya dan memakainya kembali. ${ }^{12}$

Selain mempelajari tentang ilmu eksoteris seperti tafsir, hadits, fiqh dan ilmu nahwu. Beliau juga mempelajari ilmu esoteris ke berbagai guru spiritualnya yaitu Syaikh Ahmad Khatib Sambas ibnu Abdul Ghofar yang

\footnotetext{
${ }^{11}$ Ibid, hlm. 45.

12 Op.Cit.
} 
bertempat tinggal di Jabal Qubais. MelaluiSyaikh Ahmad inilah ajaran Thariqoh Qadariyah $w a$

Naqsyabandiyah sampai kepada beliau; meskipun biasanya kedua jenis tarekat ini justru dipelajari secara terpisah. ${ }^{13}$

Beliau sering menulis karya-karya berupa risalah yang kemudian dijual seharga 200 real per kitab. Selain menjual karya-karya tulisnya, beliau pun sering membuat kaligrafi lalu menjualnya. Dengan cara inilah, beliau mampu bertahan hidup dan memenuhi kebutuhannya. Beberapa karya tulis beliau antara lain:

\section{Kitab Silah fi Bayanin Nikah}

Kitab ini menguraikan tata cara, adab dan hukum pernikahan. Dalam karya ini, pemikiran Kiai Kholil dipengaruhi oleh Imam Syafi’i.

2. Kitab Terjemah Alfiyah

Kitab ini masih berupa manuskrip dengan tulisan tangan asli beliau yang diperkirakan selesai ditulis pada tahun 1924 lengkap dengan stempel berupa cincin bertuliskan Kholil.

3. Shalawat Kiai Cholil Bangkalan

Shalawat ini disusun oleh K.H. Muhammad Kholid dalam Kitab I'anatur Roqibin dan dicetak di Pondok

${ }^{13}$ Saifur Rahman dalam Siti Fatimah, (2011), hlm. 45 .
Pesantren Rodlatul Ulum, Sumber Waringin Jember.

4. Kumpulan wirid Kiai Cholil Bangkalan

Kitab ini disusun oleh K.H. Musthofa Bisri Rembang dengan nama Kitab Haqiban.

5. Kitab Al-Matnas-Syarif al-Mulaqqab bi Fat-hil Latif

Kitab ini berisi tentang ilmu fiqh yang merupakan salah satu kajian fundamental dalam Islam. Hanya saja, kitab yang berisi 52 halaman ini pernah menjadi kitab referensi yang paling dikenal. Hal ini dikarenakan beliau menuturkan kajian fiqh dengan lebih lugas dan mudah dipahami oleh masyarakat awam sekalipun.

Kitab ini menggunakan bahasa Arab dengan terjemahan bahasa Madura di bagian bawahnya. Sampul depan kitab ini berwarna kuning, dan terdiri dari 21 pasal antara lan mengenai air, istinja, wudhu, mandi, tayamum, najis, waktu haid dan nifas, shalat, waktu shalat, fardu shalat, sunah shalat, makruh shalat, hal yang membatalkan shalat, shalat qashar dan jamak, shalat Jum'at, hal yang haram dilakukan pada shalat Jum'at. Selain itu, kitab ini juga berisi tentang tata cara memandikan, mengkafani dan menshalati mayit, zakat, puasa, i'tiqaf dan haji. Secara singkat, 
kitab ini berisikan dua bagian ibadah penting yaitu ibadah secara langsung kepada Allah maupun kepada sesama manusia.

Tidak menutup kemungkinan jika karya tulis beliau jauh lebih banyak dari apa yang telah penulis jabarkan. Hal ini terjadi karena adanya kemungkinan bahwa manuskrip beliau sudah tersebar luas. Sehingga penulis sendiri merasa kesulitan untuk menghimpunkannya menjadi sebuah penjabaran yang utuh. Apalagi jika diingat bahwa beliau sudah sering menjual hasil karyanya sejak masih belajar di Mekah.

Kiai Kholil meninggal di Marjasah, Bangkalan tepat pada tanggal 29 Ramadan 1343 Hijriyah atau sekitar tahun 1925 Masehi. Artinya, beliau meninggal pada usia sekitar 105 atau 106 tahun. Petilasan beliau yang terletak di Komplek Pasarean Syekh Muhammad Kholil, Bangkalan, Madura masih terawat hingga saat ini.

Salah satu hal menarik tentang beliau adalah tentang keberadaan lukisan beliau yang tersimpan di Museum Den Haag, Belanda. ${ }^{14}$ Hal ini menandakan bahwa ada rahasia yang menarik di balik siapa beliau dan apa saja kiprahnya dalam Islamisasi di Nusantara

\footnotetext{
${ }^{14}$ Lihat di timesindonesia.co.id. Artikel serupa juga
} dimuat di wikipedia.com. khususnya. Selain itu, beliau juga memiliki peranan penting dalam mengembangkan mazhab Syafi'i yang salah satunya beliau dapatkan dari gurunya yaitu Sayyid Ahmad bin Zaini Dahlan Syekh Nawawi al-Bantani.

\section{Kiprah dan Jaringan Intelektual}

Kiai Kholil menjadi salah satu pendakwah yang juga ikut membangun pesantren. Hal ini menjelaskan bahwa Kiai Kholil memandang pentingnya mewariskan dasar-dasar intelektualisme Islam ke dalam sebuah lembaga tradisional yang kelak akan menjadi wadah kaderisasi ulama, asatidz dan para da'i generasi selanjutnya.

Salah satu warisan ulama dalam bentuk lembaga-lembaga pendidikan Islam "tradisional" di Nusantara yang telah mencapai jumah 16.000 pesantren dan sekitar 60.000 madrasah merupakan jaringan pendidikan Islam yang paling besar dan paling luas apabila dibandingkan dengan jaringan serupa di negeri-negeri muslim yang lain. Dan itulah rahasianya, mengapa para ulama itu mampu mengislamkan sekitar $90 \%$ penduduk di Nusantara yang kini jumlahnya mencapai lebih dari 200 juta orang. ${ }^{15}$

\footnotetext{
15 Lihat Zamakhsyari Dhofier, "Sejarah Tradisi
} Pesantren", hlm. 20. 
Aktifitas keseharian di dalam pesantren pada dasarnya dapat dibedakan menjadi dua hal yaitu pertama, kegiatan internal berupa pelayanan ke dalam yaitu kepada santri. Kegiatan internal ini bisa menjadi investasi sosial bagi masyarakat. Karena pesantren melakukan internalisasi nilainilai; seperti kesederhanaan, solidaritas antarkawan, kebersihan, penghormatan kepada guru dan pemanfaatan waktu dan lain-lain. Beberapa konsepsi tersebut minimalnya telah menjadi modal dasar dalam mempersiapkan peserta didik untuk meneruskan pendidikan formal dan dalam pergaulan dengan masyarakat secara luas. Unsur-unsur inilah yang menentukan keberlangsungan pesantren dari dulu hingga saat ini.

Kedua, kegiatan yang diarahkan pada komunitas eksternal berupa pelayanan kepada masyarakat dan dunia luar. Kerja sama ini menjadi kebutuhan pesantren untuk menjaga eksistensinya dan eksistensi masyarakat secara keseluruhan. Pesantren sekarang ini dituntut untuk mengembangkan perannya yang lebih memasyarakat dan berorientasi pada penyelesaian masalah kemasyarakatan yang hidup dan sebagai lembaga sosial. Dan salah satu hal yang membuat pesantren menjadi hidup adalah dengan membawa persoalan- persoalan nyata di masyarakat ke dalam dunia pesantren. Pekerjaan sosial ini awalnya merupakan pekerjaan sampingan bahkan titipan dari pihak luar. Tetapi peran barunya ini justru akan memperluas dan mempermudah gerak usaha pesantren. Tugas kemasyarakatan yang hidup ini tidak berarti mengurangi tugas dan peran keagamaan yang selama ini menjadi tugas utamanya. Karena dapat berupa penjabaran nilai-nilai keagamaan yang tujuannya untuk kemaslahatan masyarakat. Dengan tugas baru ini pesantren akan menjadi milik bersama dan akan melihat pelaksanaan nilai-nilai hidup keagamaan dalam kehidupan sehari-hari dan bukan terbatas pada ritual saja. ${ }^{16}$

Dalam hal inilah, seorang kiai dalam pesantren harus bisa melakukan perubahan dalam kehidupan masyarakat; baik dari sisi karakter masyarakat, pola hidup, prinsip, cara pandang, intelektualitas dan lain sebagainya. Meski mungkin perubahan itu sendiri tidak dilakukan secara gradual. Tapi minimalnya, seorang kiai kemudian dituntut untuk bisa mengubah identitas masyarakatnya dengan identitas keagamaan. Sama halnya dengan Kiai Kholil yang telah menyuguhkan

16 Suyata dalam Siti Amsariah, "Pendidikan Pesantren sebagai Pengembangan Sosial", hlm. 30. 
wawasan dan cara pandang keagamaan ke dalam masyarakat Madura.

Kiai Kholil melalui pesantrennya bergerak dan bertanggung jawab untuk melakukan respon positif sekaligus juga menjadi problem solver bagi masyarakatnya. Jika tidak, maka besar kemungkinan bahwa pesantren dan dakwah yang dibawakan oleh beliau tidak akan bertahan lama. Justru, peran dan pengaruh beliau masih sangat kuat di tengah masyarakat Madura; meski saat ini beliau sudah wafat dan dakwah pun sudah dilanjutkan oleh para keturunannya.

Dalam rangka membangun pesantren sebagai wadah yang hidup, bukan berarti bahwa Kiai dalam hal ini harus membawa masyarakat untuk masuk ke dalam pesantren untuk belajar dan bermukim seperti halnya santri. Tapi lebih kepada, bagaimana pesantren melalui pemimpinnya mampu membawa persoalan hidup masyarakat yang benarbenar nyata itu ke dalam pesantren dan mencari penyelesaiannya berdasarkan kaca mata agama. ${ }^{17}$

Selain fungsi pesantren seperti di atas, pesantren juga bisa menjadi lembaga pengembangan masyarakat desa melalui pengelolaan zakat dan filantropi Islam. Hal ini terjadi karena pesantren

\footnotetext{
${ }^{17}$ Lihat Sunyata, dalam Siti Amsariah, Ibid, hlm. 31.
}

melibatkan masyarakat sebagai bentuk swadaya komunal pesantren. Sehingga pesantren tumbuh sebagai lembaga pendidikan aktif, pusat keagamaan, spiritual dan bisa juga sebagai lembaga pengelola sumbangan maupun zakat yang berupa uang ataupun benda lainnya. Jenis sumbangan berupa tanah wakaf atau bangunan sangat sering dilakukan masyarakat. Sehingga kenyataannya, penyertaan modal dari perorangan, lembaga atau masyarakat (lingkungan) memperluas dukungan terhadap kegiatan kepesantrenan tersebut. ${ }^{18}$ Meski tidak menutup kemungkinan jika, kiai dan ulama dalam hal ini hanya mengandalkan modal sendiri untuk mengembangkan pesantren yang dikelolanya. Karena kebanyakan dari mereka juga termasuk ke dalam golongan menengah, kaya dan merupakan pemilik tanah. Jika menilik dari tipologi Kiai yang diungkapkan oleh Turmudi, ${ }^{19}$ maka Kiai Kholil termasuk sebagai Kiai Pesantren dan Tarekat.

\footnotetext{
${ }^{18}$ Lihat Siti Amsariah, Ibid, hlm. 37.

${ }^{19}$ Turmudi membagi tipe kiai menjadi empat unsur yaitu sebagai berikut: (1) Kiai pesantren merupakan istilah yang ditujukan pada kiai yang memusatkan perhatiannya hanya pada aktivitas mengajar di pesantren dalam rangka meningkatkan kualitas sumber daya manusia melalui pendidikan. Tiga pihak yang terlibat dengan kiai pesantren adalah santri, wali santri dan masyarakat. Sehingga mereka akan sangat patuh dan taat pada seorang kiai; (2) Kiai tarekat adalah istilah yang ditujukan bagi seorang kiai yang memusatkan aktivitasnya dalam membangun kecerdasan hati umat Islam. Oleh
} 
Di tengah masyarakat Madura yang masih sangat kental dengan budaya patronase (ketundukan) kepada kiai ini, mereka pun menempatkan Kiai Kholil sebagai seorang ulama terbesar yang pernah ada di Bangkalan Madura. Akibatnya, Kiai Kholil memainkan banyak peran di pesantren maupun di tengah masyarakat Madura. Hal ini beliau lakukan untuk membentuk jaringan yang kuat satu sama lain, berdakwah dengan memberikan ceramah agama hingga ke pelosok desa, berpolitik secara langsung maupun tidak, serta berkonsentrasi penuh pada proses pendidikan di pesantren yang dibangunnya.

karena alasan inilah, tarekat menjadi sebuah lembaga formal yang pengikutnya juga dianggap sebagai anggota formal gerakan tarekat. Jumlah pengikut kiai model ini lebih banyak dari pengikut kiai di pesantren, tentunya kedudukan kiai tersebut sebagai mursyid atau muqaddam. Sebab, melalui cabang-cabang yang ada di seluruh Indonesia para anggota kiai tarekat secara otomatis menjadi pengikut kiai tarekat; (3) Kiai politik adalah kiai yang mempunyai perhatian utuh pada upaya pengembangan organisasi social keagamaan dan pada umumnya yang terlibat dalam politik praktis. Pengembangan organisasi social keagamaan seperti Nahdhatul Ulama atau NU dalam kurun waktu yang sangat lama dikelola oleh kiai yang masuk dalam organisasi ini. Kiai yang termasuk ke dalam tipe ini juga pada umumnya memiliki pengikut meski jumlahnya tidak sebanyak kiai tarekat maupun kiai pesantren; (4) Kiai panggung adalah mereka yang melakukan kegiatan dakwahnya dari satu panggung ke atas panggung. Maksudnya, kiai ini mengambil peranan sebagai seorang kiai yang mengisi ceramah maupun kajian dari satu tempat ke tempat lainnya. Lihat kutipan Ali Maschan Moesa dalam "Nasionalisme Kiai: Kontruksi Sosial Berbasis Agama”, Yogyakarta: LkiS, (2007: hlm 65-66).
Proses pembangunan pesantren yang dilakukan Kiai Kholil dilakukannya setelah beliau selesai belajar dari Mekah. Tepatnya pada tahun 1865, beliau mendirikan sebuah pesantren di Desa Jengkibuan, Kabupaten Bangkalan yang diberi nama Pesantren Kademangan. Pendirian pesantren ini pun telah membuat beliau berkonsentrasi untuk mengembangkan pesantrennya tersebut. Maka secara lambat laun, pesantren pun dikenal oleh banyak orang dan menjadi destinasi utama bagi mereka yang hendak berguru kepada Kiai Kholil.

Pada saat itu, metode pengajaran yang diterapkan di pesantren Kademangan bersifat tradisional (salafiyah) yang dikenal dengan metode sorogan, metode weton dan metode mudzakarah sebagaimana yang diterapkan di pesantren salaf pada umumnya. Sehingga orientasi pendidikan di pesantren ini diarahkan pada penanaman nilai-nilai keimanan yang luhur, pembentukan moral dan menjunjung tinggi nilai-nilai spiritual, mendidik sikap dan tingkah laku yang jujur dan bermoral. Sistem dan proses belajar mengajar dilaksanakan dalam bentuk nonformal. Manajemen pesantren pun masih cukup sederhana, bahkan struktur kepengurusan pesantren belum 
terbentuk, mengingat pada saat itu belum dibutuhkan undang-undang dan tata tertib pesantren. ${ }^{20}$

Format pendidikan dan pengajaran yang dikelola serta dikembangkan sejak awal berdirinya pesantren Kademangan terfokus pada bidang keagamaan murni melalui pengajian kitab-kitab salaf atau yang dikenal dengan kitab kuning atau kitab fikih. Kitab ini masih digunakan sampai sekarang karena isinya mengandung nilai universal yang menyangkut permasalahan Islam dalam kehidupan sehari-hari. Keberadaan fikih sebagai materi pembelajaran merupakan hal yang sangat penting karena rumusan hukum atas permasalahan Islam harus disandarkan sesuai hukum yang berlaku yaitu Al-Qur'an dan Hadits.

Selain mempelajari kitab kuning, Pesantren Kademangan juga menggunakan kitab-kitab referensi lainnya seperti Safinat an-Najah, Kitab Bulug al-Maram, Kitab Fath al-Qarib dan kitab yang merupakan tulisan asli dari Kiai Kholil yaitu Kitab al-Matn asSyarif. Setelah dirasa pesantren tersebut berkembang dengan pesat, beliau pun kemudian mewariskan pengelolaan

\footnotetext{
${ }^{20}$ Lihat Syariati Umami, (2012: hm. 51-52).
}

pesantren kepada menantunya yang bernama Doro Muntaha. $^{21}$

Setelah itu, Kiai Kholil mendirikan sebuah pesantren baru yang tidak jauh dari lokasi pesantren sebelumnya. Letak pesantren barunya ini sangat strategis, bahkan hampir berada di pusat kota. Tepatnya di Desa Kademangan, sekitar 200 meter dari alun-alun Kota Bangkalan.

Selain sangat rajin belajar, Kiai Kholil juga rajin untuk berbagi ilmu kepada murid-muridnya. Beliau memiliki dua hal utama dalam ranah keilmuan yaitu belajar dan mengajarkan. Di pesantrennya itu, sang Kiai membangun jejaring intelektual ulama yang tersebar hingga ke pelbagai pelosok negeri. Adapun nama-nama murid yang pernah menjadi muridnya antara lain:

1. K.H. Muhammad Hasan Sepuh, pendiri Pesantren Zainul Hasan Genggong, Probolinggo.

2. K.H. Hasyim Asy'ari, pendiri organisasi Nahdlatul 'Ulama yang juga mendirikan Pondok Pesantren Tebuireng, Jombang.

3. K.H. Abdul Wahab Hasbullah, pengasuh Pondok Pesantren Tambak Beras, Jombang.

4. K.H. Bisri Syansuri, pengasuh Pondok Pesantren Denanyar, Jombang.

\footnotetext{
21 Beliau adalah seorang Kiai muda yang masih kerabat dekat dan berdarah ningrat. Kiai Doro sendiri dikenal sebagai sosok kiai yang alim, berwibawa dan berbakat.
} 
5. K.H. Manaf Abdul Karim, pendiri Pondok Pesantren Lirboyo, Kediri.

6. K.H. Ma'sum, yang ikut serta berdakwah di Lasem, Rembang.

7. K.H. Munawir, pendiri Pondok Pesantren Al-Munawwir Krapyak, Yogyakarta.

8. K.H. Bisri Mustofa, pendiri Pondok Pesantren Raudlatut Thalibin, Rembang.

9. K.H. Nawawi, pengasuh Pondok Pesantren Sidogiri, Pasuruan.

10. K.H. Ahmad Shiddiq, pengasuh Pondok Pesantren Salafiyah Syafi'iyah, Asembagus, Situbondo.

11. K.H. Abdul Majjid, Batabata, Pamekasan.

12. K.H. Toha, pendiri Pondok Pesantren Batabata, Pamekasan.

13. K.H. Abi Sujak, pendiri Pondok Pesantren Astatinggi, Kebunagung, Sumenep.

14. K.H. Usymuni, pendiri Pondok Pesantren Pandian, Sumenep.

15. K.H. Zaini Mun'im, Paiton, Probolinggo.

16. K.H. Khozin, Buduran, Sidoarjo.

17. K.H. Abdullah Mubarok, pendiri Pondok Pesantren Suryalaya, Tasikmalaya.

18. K.H. Mustofa, pendiri Pondok Pesantren Macan Putih, Blambangan.

19. K.H. Asy'ari, pendiri Pondok Pesantren Darut Tholabah, Wonosari, Bondowoso.

20. K.H. Sayyid Ali Bafaqih, pendiri Pondok Pesantren Loloan Barat, Bali.

21. K.H. Ali Wafa, Tempurejo, Jember.

22. K.H. Munajad, Kertosono, Nganjuk.

23. K.H. Abdul Fatah, pendiri Pondok Pesantren Al-Fattah, Tulungagung.
24. K.H. Zainul Abidin, Kraksaan, Probolinggo.

25. K.H. Zainuddin, Nganjuk.

26. K.H. Abdul Hadi, Lamongan.

27. K.H. Zainur Rasyid, Kironggo, Bondowoso.

28. K.H. Karimullah, pendiri Pondok Pesantren Curah Damai, Bondowoso.

29. K.H. Muhammad Thohir Jamaluddin, pendiri Pondok Pesantren Sumber Gayam, Madura.

30. K.H. Hasan Mustofa, Garut.

31. K.H. Raden Fakih Maskumambang, Gresik.

32. Ir. Soekarno, Presiden Republik Indonesia pertama. Menurut penuturan K.H. As'ad Samsul Arifin, Bung Karno menjadi murid tidak resmi Kiai Kholil.

Beberapa di antara nama tersebut di atas, kemudian dikenallah beberapa tokoh penting dalam Islamisasi Nusantara melalui organisasinya masingmasing. Di antara murid yang penulis maksud antara lain, Kiai Hasyim Asy'ari yang berasal dari Jombang yang kelak mendirikan organisasi Islam terbesar di Pulau Jawa yang bernama Nahdlatul Ulama (NU). Lahirnya organisasi terbesar di Jawa itupun merupakan hasil dari proses kreatif Kiai Kholil yang telah melibatkan diri dalam mewadahi kemampuan dakwah santrinya di bidang politik. Teman seangkatan Kiai Hasyim Asy'ari yang sama-sama berguru kepada Kiai Kholil adalah K.H. Amien Sepuh 
yang merupakan pengasuh Pesantren

Babakan Cirebon.

Santri Kiai Kholil lainnya yang cukup aktif berjuang pada masa revolusi kemerdekaan adalah K.H. Abdullah Sajjad, putra Kiai Muhammad Syarqawi $^{22}$ (w. 1910) dan Nyai Qamariyah. Beliau yang terlahir sebagai putra daerah Guluk-Guluk Sumenep Madura itu memiliki tugas dan kewajiban untuk meneruskan sepak terjang ayahnya untuk mengelola Pesantren Annuqayah yang telah didirikan pada tahun 1887. Dan pada saat agresi militer Belanda II tahun 1947, beliau memimpin Laskar Sabilillah ${ }^{23}$ di Sumenep.

\footnotetext{
${ }^{22}$ Beliau adalah sahabat Kiai Kholil. Mereka berdua telah menjadi dua tokoh penting yang dianggap sebagai poros jaringan ulama Madura. Dimana Kiai Kholil lebih banyak bergerak di wilayah Madura bagian barat. Sedangkan sahabatnya itu bergerak di Madura bagian selatan.

${ }^{23}$ Laskar Sabilillah adalah salah satu laskah para pejuang Madura yang aktif melakukan perlawanan terhadap penjajahan Belanda. Selain Sabilillah, para pemuda Madura membentuk Seinendan, Keibodan serta sisa-sisa Korps Barisan Madura, para mantan tentara PETA dan Heiho serta Hizbullah, Pemuda Republik Indonesia dan Pemuda Sosialis Indonesia (Pesindo). Para Kiai dan pemuda Islam di daerahnya ini bahkan telah membentuk satuan-satuan paramiliter. Berbekal pengalaman intelektual di organisasi militer modern seperti PETA dan Hizbullah, mereka bahkan menjadikan daerah Besuki sebagai Heillige Zone (zona suci) yang terbentang mulai dari Banyuwangi di Tapal Kuda (pesisir timur Pulau Jawa), menjadi benteng laskar ulama santri. jaringan ini juga yang telah mementahkan rencana Kolonial Belanda membentuk Negara Madura dan Negara Jawa Timur pasca Perjanjian Renville. Meskipun pada 3 Desember 1948 berdiri Negara Jawa Timur, namun tidak berjalan efektif dan massif sehingga Jawa Timur
}

Kiai Kholil juga telah mendidik K.H. As'ad Syamsul Arifin yang merupakan salah satu mediator lahirnya NU sekaligus juga pengasuh Pondok Pesantren Salafiyah Syafi'iyah Sukorejo, Situbondo, Jawa Timur. Selain itu, beliau juga dikenal sebagai seorang ulama besar yang pandai dalam ilmu beladiri. Setelah menempuh pendidikan yang lama mulai dari Kiai Kholil hingga sampai ke Yaman, beliau akhirnya kembali ke tanah air pada tahun 1924 dan bergabung dalam barisan HibzullahSabilillah bersama dengan Kiai Zainul Arifin, Kiai Bisri Sjansuri, Kiai Badrus Sholeh Kediri dan Kiai Bajuri. Setelah mengikuti pertemuan yang mencetuskan Resolusi Jihad, beliau yang pada saat itu menjadi Pimpinan Sabilillah Jawa Timur bagian timur pun langsung melakukan konsolidasi dan sosialisasi ke beberapa daerah Jawa Timur hingga ke seluruh kabupaten di Madura. $^{24}$

Santri Kiai Kholil lainnya yang berasal dari Madura adalah K.H. Zaini Abdul Mun'im. Beliau terlibat aktif dalam perjuangan membela hak-hak rakyat, mebela keutuhan bangsa dan Negara Kesatuan Republik Indonesia.

kembali ke pangkuan RI di Jogyakarta pada 13 Januari 1950. Lihat: Zainul Milal Bizawie, Masterpiece Islam Nusantara: Sanad dan Jejaring Ulama-Santri (1830-1945), Jakarta: Pustaka Compass, (2016: hlm. 65-66).

${ }^{24}$ Zainul Milal Bizawie, Ibid., (2016: hlm. 70). 
Pada masa penjajahan Jepang, beliau dipercaya sebagai pimpinan Barisan Pembela Tanah Air (PETA). Selanjutnya, pada masa perang kemerdekaan, beliau juga dipercaya sebagai pimpinan Sabilillah ketika melakukan Serangan Umum tanggal 16 Agustus 1947 terhadap tentara Belanda yang menguasai Kota Pamekasan. Beliau termasuk sebagai tokoh pejuang menjadi target operasi Belanda, yang dikejarkejar karena kegigihannya dan sikap pantang menyerah dalam melawan kekuatan penjajah. $^{25}$

Selain di Situbondo dan Probolinggo, santri Kiai Kholil di Tapal Kuda yang cukup gigih melawan Kolonialisme Belanda adalah K.H. Saleh Lanteng Banyuwangi. Beliau adalah seorang pendekar sakti keturunan Kesultanan Palembang Sumatera. Selama di Bangkalan, beliau belajar berbagai ilmu termasuk ilmu-ilmu kesaktian yang kelak akan digunakan secara langsung untuk memperbaiki masyarakatnya. Selain itu, beliau juga bergabung dengan Sarekat Islam dan pada tahun 1913 menjadi pimpinan Rapat Umum Sarekat Islam yang diadakan di Kawedanan Glenmore Banyuwangi. ${ }^{26}$

${ }^{25}$ Zainul Milal Bizawie, Ibid., (2016:72).

${ }^{26}$ Zainul Milal Bizawie, Ibid., (2016:76).
Selain nama-nama tersebut di atas, santri Kiai Kholil yang juga menjadi tokoh penting adalah K.H. Asy'arie Wonosari. Beliau memiliki kemampuan untuk merangkul para penjahat untuk kembali kepada ajaran Islam dan melawan penjajah. Wilayah Bondowoso pada awal tahun 1930 atau sebelum kemerdekaan, merupakan bagian dari Karesidenan Besuki. Karesidenan ini merupakan pusat pemerintahan di daerah Tapal Kuda dan sekitarnya, dibentuk oeh pemerintah Kolonial Belanda dalam rangka mengatur kebijakan penanaman dan penjualan barang-barang komoditi khususnya tembakau serta memperlancar arus perdagangan melalui pelabuhanpelabuhan laut. K.H. Asy'arie merupakan perintis awal atau tokoh awal penyebar agama Islam di Wonosari. Beliau juga mendirikan Pondok Pesantren Daruth Tholabah serta menjadi Pembina Pertama Jam'iyah Nahdlatul Ulama di wilayah Kabupaten Bondowoso. Pondok ini kemudian menjadi basis pengembangan ilmu agama, perjuangan kemerdekaan dan perlawanan terhadap penjajah. ${ }^{27}$

D. Tarekat Qadariyah Wa anNaqsyabandiyah: Peran dan

\section{Pemikiran}

${ }^{27}$ Zainul Milal Bizawie, Ibid., (2016:80). 
Seperti telah disebutkan di atas, Kiai Kholil tidak hanya mempelajari ilmuilmu eksoteris, tetapi juga ilmu esoteris ke berbagai guru spiritualnya yaitu Syaikh Ahmad Khatib Sambas ibnu Abdul Ghofar yang bertempat tinggal di Jabal Qubais. Syaikh Ahmad inilah yang mengajarkan tentang Thariqoh Qadariyah wa Naqsyabandiyah kepada beliau. Padahal biasanya kedua jenis tarekat ini justru dipelajari secara terpisah. $^{28}$

Tarekat Qadiriyah wa anNaqsyabandiyah merupakan perpaduan dari dua buah tarekat dari Qadiriyah dan Naqsyabandiyah yang didirikan oleh Syaikh Achmad Khatib al-Syambasi di Mekah pada awal abad ke-13 $\mathrm{H}$ atau 19 M. Tarekat ini telah diakui sebagai tarekat yang mu'tabarah (diakui keabsahannya).Tarekat ini menjawab keresahan umat akan muncul dan berkembangnya ajaran wihdah al-wujud yang lebih cenderung memiliki konotasi panteisme dan kurang menghargai syariat Islam. Meskipun begitu, tarekat ini mengakomodasi paham modernisme yang juga mengakomodasi kecenderungan mistis dan sufistik masyarakat Islam.

${ }^{28}$ Saifur Rahman dalam Siti Fatimah, (2011), hlm. 45.
Seperti namanya, tarekat ini menggabungkan dua aliran tarekat sebelumnya tanpa menghilangkan kekhasan masing-masing. Maka, tarekat ini tetap menggunakan dzikir Jahar Nafi Itsbat yang merupakan wirid wajib Tarekat Qadiriyah dengan dzikir Sirri Ism Dzat yang merupakan wirid wajib Tarekat Naqsyabandiyah. Bahkan, tarekat ini dianggap sebagai penggabungan dan modifikasi ajaran inti dari lima tarekat lainnya yaitu Qadiriyah, Naqsyabandiyah, Anfasiyah, Junaidiyah dan Muwafaqah (Samaniyah).

Ajaran dari tarekat ini didasarkan kepada Al-Qur'an, Hadits dan perkataan para 'ulama arifin dari kalangan salafus Shalihin. Sedangkan untuk inti ajarannya antara lain menyangkut tetang kesempurnaan suluk, adab (etika), dzikir dan muraqabah.

Tarekat Qadariyah wa anNaqsyabandiyah di Madura yang dibawa oleh Kiai Kholil memiliki silsilah dari jalur Syaikh Ahmad Khatib Sambas antara lain:

1. Allah Swt

2. Jibril a.s

3. Nabi Muhammad Saw

4. Ali bin Abi Thalib

5. Husein bin Ali

6. Ali Zainal Abidin 
7. Muhammad Baqir

8. Ja'far ash-Shodiq

9. Imam Musa al-Kazhim

10. Abu Hasan Ali ibn Musa al-Ridha

11. Ma'ruf al-Karkhi

12. Sirrias-Saqathi

13. Abu Qosim al-Junaidi al-Baghdadi

14. Abu Bakar Sibliy

15. Abu Fadli Wahidi at-Tamimi

16. Abu Farazi at-Thurthusil

17. Abu Hasan Ayyub

18. Abu Said al-Mubarok

19. Abdul Qadir Jailani

20. Abdul Aziz

21. Muhammad al-Hattak

22. Syamsuddin

23. Syarifuddin

24. Nuruddin

25. Waliyuddin

26. Hisyamuddin

27. Yahya

28. Abu Bakar

29. Abdurrohim

30. Utsman

31. Abdul Fattah

32. Muhammad Murad

33. Syamsuddin

34. Ahmad Khatib Sambas

35. Muhammad Kholil Bangkalan ${ }^{29}$

Kiai Kholil tidak pernah dibaiat dan tidak pernah memberikan ijazah tarekat kepada siapapun. Karena beliau merasa bahwa untuk menjadi seorang murid saja sudah sangat berat apalagi menjadi seorang mursyid. Meskipun demikian, tak sedikit murid beliau yang kemudian menganut tarekat yang sama dengannya. Di antara nama para murid itu antara lain Kiai Hasyim Asy'ari, Kiai As'ad Syamsul Arifin, Kiai Abdullah Mubarak (Abah Sepuh) dan masih banyak lainnya. Mereka memang tidak belajar ilmu tarekat kepada Kiai Kholil tapi kepada guru lainnya.

Dalam hal tarekat, Kiai Hasyim Asy'ari pun memiliki pandangan yang sama dengan Kiai Kholil, bahwa menjadi seorang murid tarekat saja sudah sangat sulit. Maka, wajar ketika kemudian, Kiai Hasyim Asy'ari pun tidak pernah dibaiat dan memberikan ijasah kepada orang lain. Hal yang sama juga terjadi pada Kiai As'ad. Meski beliau menjadi penganut tarekat yang taat, tetapi beliau tidak pernah sekalipun mengajak santrinya untuk mempelajari dan mengamalkan tarekat, apalagi mengajarkannya. Kiai As'ad memandang bahwa tarekat itu sangat berat konsekuensinya. Orang yang mengikuti tarekat, jika imannya belum cukup kuat, ilmu agamanya belum cukup

${ }^{29}$ Siti Fatimah, (2011: hlm. 47-48). 
luas dan belum cukup usia akan tersesat ke dalam kemusyrikan. ${ }^{30}$

Cara yang dilakukan oleh Kiai Hasyim dan Kiai As'ad pada akhirnya sama dengan sikap dari gurunya yaitu Kiai Kholil. Mereka tidak pernah mengajarkan, menyebarkan ataupun membaiat satu orang pun untuk masuk ke dalam tarekat Qadiriyah wa anNaqsyabandiyah. Meski tidak melakukan hal itu, tapi apa secara tidak langsung tarekat yang Kiai Kholil anut ini kemudian menjadi inspirasi keilmuan bagi para muridnya.

\section{E. Penutup}

Tidak banyak uraian tentang Kiai Kholil yang berhasil penulis temukan secara terperinci. Tetapi dari paparan di atas setidaknya ada gambaran tentang Kiai Kholil dalam proses Islamisasi di Nusantara.

Pada saatnya kemudian Kiai Kholil ini dapat dikatakan sebagai ulama lokal tapi jaringannya sudah berskala nasional dan internasional di mana seperti banyak diketahui bahwa Haramayn adalah dua tempat yang berfungsi sebagai produsen bagi jaringan keilmuan Islam dalam menghasilkan jejaring ulama-santri yang bersifat global.

\footnotetext{
${ }^{30}$ Saifullah Ma'shum dalam Alzani Zulmi M, Ibid., hlm. 98.
}

Dan seperti uraian di atas, di mana keberhasilan seorang kiai adalah ketika dapat menghasilkan murid yang menjadi kiai lagi, tetapi tidak hanya sebatas itu, Kiai Kholil mampu memposisikan dirinya sebagai ulama-santri dan santriulama ketika yang dikedepankannya adalah berdasarkan keilmuan seseorang.

Wallahua'lambisshawab.

\section{Daftar Pustaka}

Amsariah, Siti. 2008. Pendidikan Pesantren sebagai Pengembangan Sosial. Ciputat: Direktorat Pendidikan Diniyah dan Pondok Pesantren Departemen Agama RI bekerjasama dengan IRD.

Bizawie, Zainul Milal. 2016. Masterpiece Islam Nusantara: Sanad dan Jejaring Ulama-Santri (1830-1945). Jakarta: Pustaka Compass.

Dhofier, Zamakhsyari. 2008. Sejarah Tradisi Pesantren. Ciputat: Direktorat Pendidikan Diniyah dan Pondok Pesantren Departemen Agama RI bekerjasama dengan IRD.

Ma'arif, Samsul. 2005. The History of Madura: Sejarah Panjang Madura dari Kerajaan, Kolonialisme sampai Kemerdekaan. Yogyakarta: Araska.

Moesa, Ali Maschan. 2007. Nasionalisme Kiai: Konstruksi Sosial Berbasis Agama. Yogyakarta: LKiS.

Rahman, Saifur. 1999. Biografi dan Karomah K.H. Mohammad Kholil Bangkalan: Surat kepada Anjing Hitam. Jakarta: Pustaka Ciganjur.

Sahal, Ahmad, dkk. 2016. Islam Nusantara: dari Ushul Fiqh Hingga Paham Kebangsaan. Bandung: P.T. Mizan Pustaka. 
Umami, Syariati, 2012, "Sosialisasi Fikih Muhammad Kholil di Bangkalan", Skripsi. Jakarta: Universitas Indonesia.

\section{Sumber Lain:}

Timesindonesia.co.id

Fatimah, Siti, 2011, "Peran K.H. Wikipedia.com Muhammad Kholil dalam Kamus Besar Bahasa Indonesia. Mengembangkan Islam di BangkalanMadura", Skripsi. Jakarta: UIN Syarif Hidayatullah. 